V. Mozgovyi, Ph. D.

Taras Shevchenko National University of Kyiv, Kyiv

\title{
RESEARCH OF STRUCTURAL ORGANIZATION OF THE PERSONALITY OF MILITARY SERVICE CIRCULAR TO ALCOHOLEXTREMELY IN THE CONTEXT OF THEIR GENDER-ROLE STATUS
}

The article deals with the features of the structural organization of the personality of the servicemen who are prone to alcohol abuse. Determined the further focus of the psychologist's part with this category of persons, depending on the identified sex-role status of servicemen who are prone to alcohol abuse. According to the purpose the following tasks have been set: To investigate the specifics of the factor structure of servicemen who are prone to alcohol abuse; Identify the main pivotal features of their psychological portrait; To outline the main ways of psycho-corrective work with the personnel, who are prone to alcohol abuse depending on sexual role status. In total, 64 servicemen of the State Special Transport Service (MoDST) of the Ministry of Defense of Ukraine participated in the study. Research methods are: Prognosis, SZCh-4, HADS, CP-10, Kettel's personal questionnaire, Shmishek's test, self-esteem questionnaire, S. Bem method (determination of level of masculinity / femininity assessment) and structural gender-role scale (A. Kocharyan - EV Frolova), as well as Dur-Moll (masculinity-femininity, respectively) by S. Sondi's method. The study revealed the character traits of a psychological portrait of servicemen who are prone to alcohol abuse: excitability, cyclothymia, anxiety, non-conformism and abusive behavior. The following key core personality indicators have been identified such as neuropsychiatric resistance, risk of nerve failure, and personal readiness to use inverted dynamics weapons. The focus of psycho-corrective influence of part of the psychologist on the personality of alcohol addicted servicemen should be to conduct training sessions aimed at forming a positive image of the serviceman.

Keywords: factor structure of the person, sex-role status, serviceman.

Bulletin of Taras Shevchenko National University of Kyiv. Series "Psychology". № 2(9), pp. 47-51 (2018)

УДК 159.97

DOI: https://doi.org/10.17721/BSP.2018.2(9).12
ISSN 1728-3817

(C) Taras Shevchenko National University of Kyiv, Publishing Center "Kyiv University", 2018

В. Морозова, студ.

\section{ПСИХОЛОГІЧНІ ОСОБЛИВОСТІ ОСІБ ІЗ МЕЖОВИМ РОЗЛАДОМ ОСОБИСТОСТІ}

Подано результати емпіричного дослідження психологічних особливостей осіб із ознаками межового розладу особистості. Доведено, що емоційна лабільність (нестійкість емоцій), імпульсивність та самоушкоджувальна поведінка є важливими діагностичними критеріями межового розладу особистості. Високий рівень вияву ознак межового розладу особистості супроводжується такими психічними станами дезадаптації, як невротична депресія, астенія, напруженість і тривожність.

Ключові слова: межовий розлад особистості, невротичні стани, нестійкість емоцій, самоушкоджувальна поведінка, імпульсивність, тривожність.

Постановка проблеми. Сучасний стан ситуації психічного здоров'я в нашій країні відображається у звіті Міністерства соціальної політики України за 2017 р., де йдеться про те, що Україна посіла перше місце в Європі за кількістю психічних розладів. За офріційною статистикою, в Україні 1,2 млн мешканців (більше $3 \%$ ) страждає психічними розладами і щорічно майже 2 млн осіб стають пацієнтами психіатричних лікарень [8]. Зазначимо, що межовий розлад особистості $\epsilon$ серйозною і багатоаспектною, але все ще маловивченою проблемою. У Міжнародній класифікації хвороб MKX-10 відсутнє чітке визначення межового розладу особистості; воно розглядається як різновид емоційного нестійкого розладу (F60.3). У більш вузькоспеціалізованому класифікаторі психічних розладів DSM-5 даний розлад позначено окремим пунктом (301.83). Особлива увага дослідників даної проблеми приділяється питанням діагностики, причинам виникнення і розвитку межового розладу особистості. Поняття "межовий розлад особистості" $\epsilon$ відносно новим у психопатології. Воно не входило в діагностичні посібники із психічних розладів Американської психіатричної асоціації до 1980 р. (у цьому році з'явилося перероблене і доповнене видання Diagnostic and Statistical Manual of Mental Disorders DSM-III). Особливо гострим моментом проблеми є той фракт, що для осіб із МРО характерні суїцидальні думки та спроби, а також парасуїцидальна поведінка, самоушкодження тощо. Одним із найбільших страхів людей із MPO є страх розриву значущих і близьких відносин. Особи з МРО дуже бояться самотності, але при цьому в них відсутне розуміння того, що їх прагнення утримати партнера відлякує його. На самоті у них можуть спостерігатися виражені стани деперсоналізації та дереалізації й перемикання між цими станами. Різкі стрибки у відносинах призводять до афектів (тривоги, сорому, самозвинувачення і самоприниження, залучення до саморуйнівної поведінки тощо). Розрив відносин із значущою особою $\epsilon$ величезним стресом для людини 3 межовим розладом особистості. Якщо людина 3 МРО відчуває себе покинутою, вона може впадати в паніку, депресію, або навпаки, гнів, може також піти на відчайдушні вчинки. Реакції людини в ситуації стресу дозволяють визначити наявність МРО. У ситуації стресу в людей із межовим розладом особистості можуть спостерігатися дестабілізація в когнітивній, поведінковій та емоційній сфрерах, а також дезадаптація.

Аналіз досліджуваності проблеми. Останні роки значно підвищився інтерес до проблеми межового розладу особистості (MPO) як серед психологів, так і серед представників суміжних наукових галузей (медицині, психіатрії). Це обумовлено тим фактом, що у пацієнтів 3 різними формами розладів особистості, симптоми МРО спостерігаються приблизно в $33 \%$ амбулаторних, та у $63 \%$ хворих, що проходять лікування у стаціонарних відділеннях [3, с. 6-7].

А. Штерн (1939) описав хворих, які проходять амбулаторне лікування і яким не допомагав класичний психоаналіз, а також таких, які не вписувалися в категорії "невротичних" або "психотичних" пацієнтів. С. Радо (1956) позначав межовий розлад особистості як "екстрактивний розлад". С. Лессер і Б. Ессер (1965) позначали МРО як "істероідний розлад". Загальні ознаки, властиві особам із МРО, виділяли Р. Грінкер, Р. Драй і Б. Вербль (1968).

Серед сучасних дослідників проблеми межового розладу особистості особливої уваги заслуговує досвід американського психолога, засновниці діалектикоповедінкової терапії М. Лайнен. Вона виділяє низку поведінкових паттернів при межовому розладі особистості та упроваджує доволі ефективні методи подолання межового розладу особистості [3].

Зазначимо, що межовий розлад особистості - це розлад психіки, за якого зазначається емоційна нестабільність поведінки. Особи з межовим розладом особистості мають ряд психологічних особливостей, які ускладнюють процес їх соціальної адаптації. Різкі перепади настрою, афективна нестійкість, імпульсивність, дратівливість - усе це несприятливо позначається на взаєминах з іншими людьми. Оточення схильне приписувати такій людині "важкий характер" і цуратися його, або ж вороже до нього 
ставитися. Це не може не позначатися на людині з МРО внаслідок того, що такі люди дуже потребують побудови й підтримки довгострокових і глибоких відносин.

Мета статті: розкрити результати дослідження психологічних особливостей особистості осіб із межовим розладом особистості.

Виклад основного матеріалу дослідження й обґрунтування отриманих результатів.

Межовий розлад особистості - це важка дисфункція системи емоційної регуляції. Ця дисфункція виникає через біологічні порушення і взаємодії індивіда з дисфункціональним оточенням.

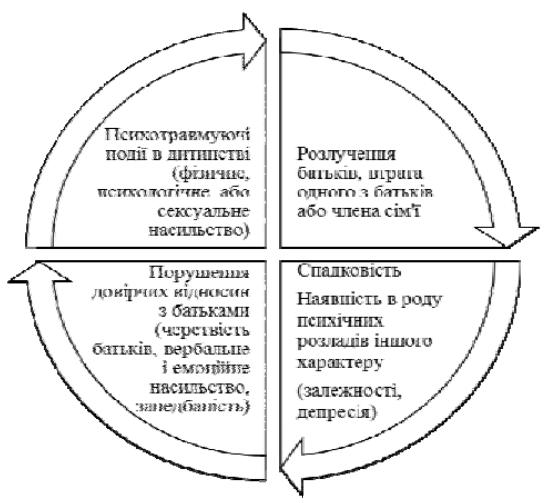

Рис. 1. Чинники, що сприяють виникненню та вияву межового розладу особистості

До причин виникнення межового розладу особистості прийнято відносити такі фрактори, як: спадковість, наявність у роду психічних розладів іншого характеру (залежності, депресія), розлучення батьків, утрата одного з батьків або члена сім'ї, порушення довірчих відносин із батьками (черствість батьків, вербальне й емоційне насильство, занедбаність), психотравмуючі події в дитинстві (фрізичне, психологічне або сексуальне насильство), нездорова атмосфера в родині, утрата значущого дорослого, низька стресостійкість, тривожність як риса характеру, обумовлена темпераментом підвищена вразливість і загальна вразливість.

У ході проведення емпіричного дослідження, для участі у процедурі психологічної діагностики були задіяні добровільно, при збереженні конфіденційності одержуваної інформації особи із виявами ознак межового розладу особистості. Емпіричну базу нашого дослідження становили 40 осіб із ознаками межового розладу особистості віком 14-56 років (середній вік21,9 років). Серед респондентів: 30 жінок (75\%) і 10 чоловіків (25\%). У всіх осіб спостерігаються ознаки межового розладу особистості, що і було основним критерієм відбору випробовуваних для нашого дослідження. Ознаки межового розладу особистості виділялися в ході проведення попереднього опитування респондентів для виявлення наявності можливих ознак даного розладу, що в подальшому перевірялося за допомогою спеціалізованої методики діагностики межового розладу особистості, розробленої Т. Ю. Ласовською, Ц.П.Короленко та С. В. Яєчниковим [2]. Відбір осіб для подальшого аналізу зазначеної вище проблеми здійснювався виходячи 3 наявності не менше п'яти ознак із можливих дев'яти, включених у діагностичний і статистичний посібник із психічних розладів DSM-IV та DSM-IV-TR.

Для проведення емпіричного дослідження нами були використані такі методики: методика 5PFQ "Велика П'ятірка" (Р. МакКрае, П. Коста), Клінічний опитувальник для виявлення й оцінки невротичних станів (К. К. Яхін, Д. М. Менделєвич) та Методика діагностики межового розладу особистості (Т. Ю. Ласовська, Ц. П. Короленко, С.В.Яєчников). Середні показники результатів дослідження подано у табл. 1.

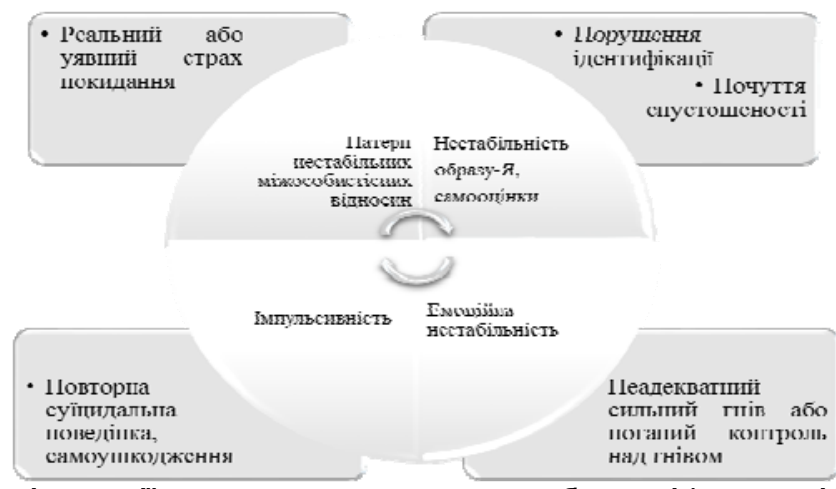

Рис. 2. Діагностичні критерії ознак межового розладу особистості (на основі DSM-IV та DSM-IV-TR)

Таблиця 1

Зведена таблиця середніх значень результатів за методиками

\begin{tabular}{|c|c|c|c|}
\hline № & Показник & Середнє значення (X ср.) & Стандартне відхилення ( $\sigma)$ \\
\hline \multicolumn{4}{|c|}{ Методика Велика П'ятірка "5PFQ" } \\
\hline 1 & Інтроверсія - екстраверсія & 44,3 & 11,40 \\
\hline 2 & Відособленість - прихільність & 46,9 & 10,96 \\
\hline 3 & Імпульсивність - самоконтроль & 45,7 & 11,14 \\
\hline 4 & Емоційна нестійкість & 63,4 & 8,19 \\
\hline 5 & Практичність - експресивність & 53,6 & 9,17 \\
\hline \multicolumn{4}{|c|}{ Клінічний опитувальник (К. К. Яхін, Д. М. Менделєвич) } \\
\hline 1 & Шкала тривоги & $-4,74$ & 4,29 \\
\hline 2 & Шкала невротичної_депресії & $-7,86$ & 4,30 \\
\hline 3 & Шкала астенії & $-6,23$ & 4,54 \\
\hline 4 & Шкала конверсійного розладу & $-4,87$ & 4,76 \\
\hline 5 & Шкала обсесивно-фробічного розладу & $-4,72$ & 3,62 \\
\hline 6 & Шкала вегетативних порушень & $-8,72$ & 8,17 \\
\hline \multicolumn{4}{|c|}{ Методика діагностики межового розладу особистості (МРО) } \\
\hline 1 & Кількість ознак МРО & 6,8 & 0,97 \\
\hline 2 & Інтегральний показник MPO & 15,43 & 2,66 \\
\hline
\end{tabular}


Методика діагностики межового розладу особистості (MPO) являє собою особистісний опитувальник, розроблений на основі діагностичних критеріїв даного розладу особистості згідно з діагностичним і статистичним посібником про психічні розлади DSM-III-R і DSM-IV. Методика розроблена у 2012 р. колективом авторів (Т. Ю. Ласовська, Ц. П. Короленко, С.В.Яєчників) [2].

У нашому дослідженні була застосована коротка форма опитувальника S, що складається із 20ти тверджень, які відображають дев'ять діагностичних критеріїв межового розладу особистості. Для діагностики MPO необхідна наявність, крім загальних критеріїв розладів особистості, п'ять або більше з таких критеріїв: патерн нестабільних міжособистісних відносин (запитання № 1); імпульсивність хоча б у двох сорерах, які $€$ потенційно самопошкоджувальними (запитання № 24); емоційна нестабільність (№ 5-6); неадекватний сильний гнів або поганий контроль над гнівом (№ 7-8); повторна суїцидальна поведінка, самоушкодження (№ 9-12); порушення ідентиффікації (№ 13-14); хронічне відчуття порожнечі (№ 15-16); реальний або уявний страх покидання (№ 17-18). До додаткових критеріїв належать інтерес до смерті (№ 19) і сильні почуття при вигляді крові (№ 20).

У ході проведення дослідження наявності ознак межового розладу особистості було встановлено таке співвідношення кількості ознак МРЛ: п'ять ознак спостерігається у $15 \%$, шість ознак зустрічається у $25 \%$, сім ознак у $37,5 \%$ випробуваних, вісім ознак - у $22,5 \%$. Таким чином, у всіх випробовуваних спостерігається достатня кількість діагностичних ознак MPO, що дозволяє припускати наявність межового розладу особистості, але для уточнення й постановки діагнозу, рекомендується звернутися до фахівця (психотерапевт, лікар-психіатр).

Для уточнення психологічних особливостей осіб із виявами ознак межового розладу особистості було застосовано методику п'ятифакторного опитувальника особистості (автори: Р. МакКрае, П. Коста; версія "5PFQ", упорядник X. Тсуйі, адаптація А.Б. Хромова) [5]. Співвідношення середніх значень за п'ятьма фракторами методики подано гістограмою (див. рис. 3).

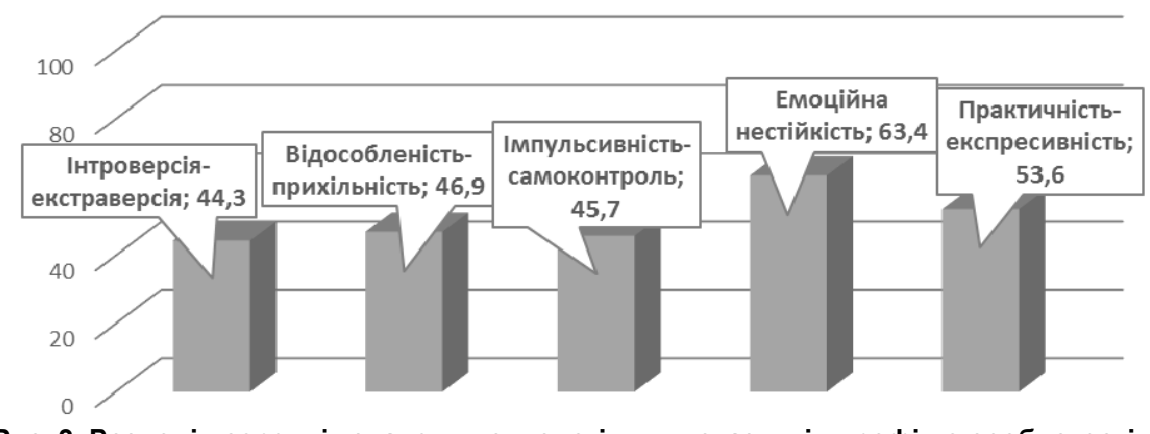

Рис. 3. Розподіл середніх значень психологічних показників профілю особистості за методикою Велика П'ятірка "5PFQ"

Фактор прихильність - відокремленість перегукується з таким важливим критерієм у діагностиці межового розладу особистості, як непереносимість самотності. За результатами нашого дослідження, середнє значення 46,9 балів належить до середнього рівня показника. Головним змістом фактора самоконтроль імпульсивність $€$ вольова регуляція поведінки. Цей фрактор є важливим при вивченні осіб із виявами ознак межового розладу особистості (МРО), оскільки саме імпульсивність входить в один із головних діагностичних критеріїв МРО. Середнє значення за вибіркою у 45,7 балів відображає загальну тенденцію аналізованих нами ознак самоконтролю - імпульсивності й належить до діапазону середнього рівня вияву даної характеристики. Низький рівень самоконтролю, і як наслідок, вияв імпульсивності, показали 30 \% випробовуваних нашої вибірки. Такому типу особистості характерні: природність поведінки, безтурботність, схильність до необдуманих учинків. Емоційна лабільність (нестійкість емоцій) також $є$ важливим діагностичним критерієм межового розладу особистості (МРО). За результатами нашого дослідження, середнє значення за вибіркою у 63,4 балів відповідає високому рівню виразності емоційної нестійкості та $€$ найвищим показником серед усіх п'яти чинників особистості досліджуваних нами осіб. Дійсно, 96,7 \% усієї вибірки (N = 40) показали високий рівень емоційної лабільності. Високі значення за цим фактором характеризують осіб, що нездатні контролювати свої емоції та імпульсивні потяги. У поведінці це виявляється як відсутність почуття відповідальності, ухилення від реальності, примхливість тощо.

Для осіб із високими значеннями експресивності притаманні легке ставлення до життя, безтурботність, біль- шою мірою, довіра своїм почуттям і інтуїції, ніж здоровому глузду. Також характерними $є$ емоційність, експресивність, добре розвинений естетичний і художній смаки. Середнє значення за групою випробовуваних становить 53,6 балів, відповідає високому рівню вияву експресивності. За результатами тестування, 66,7 \% усієї вибірки представлені високим рівнем експресивності.

Для виявлення і оцінки ступеня вияву різних невротичних станів у осіб із ознаками межового розладу особистості було застосовано методику Клінічний опитувальник виявлення та оцінки невротичних станів (автори К. К. Яхін, Д. М. Менделєвич) [6]. Показники сумарних значень вище +1,28 указують на стан стабільної психічної адаптації досліджуваних осіб. Значення, які перебувають у діапазоні від $+1,28$ до $-1,28$, свідчать про перебування людини у стані нестійкої психічної адаптації. Якщо ж результати підсумовування діагностичних коефріцієнтів потрапляють у діапазон значень нижче -1,28 балів, то можна констатувати наявність стану психічної дезадаптації у досліджуваних осіб. Розподіл середніх значень діагностичних коефіцієнтів по всіх шести шкалах у групі осіб із ознаками межового розладу особистості подано гістограмою (див. рис. 4).

У результаті проведеного психологічного тестування, у осіб із виявами ознак межового розладу особистості (MPO) середнє значення за шкалою тривоги 4,74 балів потрапляє в діапазон стану психічної дезадаптації особистості. Дійсно, 86,6 \% усіх випробовуваних показали результати нижче - 1,28 балів, що відповідає стану психічної дезадаптації. Як правило, особи з такими показниками сприймають широке коло ситуацій як загрозливі своїй самооцінці, самоповазі та в цілому життєдіяльності. Середнє значення за шкалою 
невротичної депресії потрапляє в діапазон психічної дезадаптації особистості (-7,86 балів). У 86,7\% усіх випробовуваних спостерігаються результати нижче 1,28 балів. Ознаки невротичної депресії характеризуються симптомами зниженого настрою, почуттям безрадісності, ослабленням тонусу й енергії, обмеженням контактів із оточуючими та загальним зниженням інтересів. Середнє значення астенії за вибіркою досліджуваних нами осіб із виявами ознак межового розладу особистості також потрапляє в діапазон стану психічної дезадаптації і дорівнює -6,23 бали. Зазначимо, що 93,4 \% усіх досліджуваних потрапляють у діапазон стану психічної дезадаптації за шкалою астенії. У осіб із високими значеннями астенії можливі вияви швидкої стомлюваності та, як наслідок, порушення уваги, зниження працездатності, дратівливість, емоційна нестійкість. Для осіб із високими значеннями конверсійного розладу характерний істеричний тип реагування, основні тенденції якого - вимога визнання, підвищена чутливість і вразливість, образливість, а також вияв істеричного реагування у вигляді порушеної серцевої діяльності, дихання, шлунково-кишкового тракту, мож- ливо спостерігатимуся тики і рухові порушення. Середнє значення за вибіркою $-4,87$ балів і входить у діапазон стану психічної дезадаптації. У цілому, 76,7 \% усієї вибірки дослідження перебувають у стані психічної дезадаптації конверсійного типу. Таким особам притаманні вияви потреби в отриманні уваги, нестійка самооцінка, награність поведінки, обсесивно-фообічні розлади, що характеризуються наявністю нав'язливих спогадів, сумнівів, страхів, невпевненістю у своїх вчинках і рішеннях тощо. Середній бал за всією вибіркою випробовуваних дорівнює -4,72 і належить до рівня вираженості стану психічної дезадаптації. Показники такого рівня спостерігаються у 86,7 \% усіх випробовуваних. Найбільш високий середній бал серед усіх шести шкал кліничного опитувальника спостерігається за шкалою вегетативних порушень і дорівнює -8,72 бали. Можливі вияви даного розладу: зниження апетиту, порушення серцево-судинної діяльності, шлунковокишкові розлади, порушення терморегуляції, порушення сну, головні болі. Стан психічної дезадаптації за шкалою вегетативних порушень спостерігається у $76,7 \%$ усіх учасників дослідження.

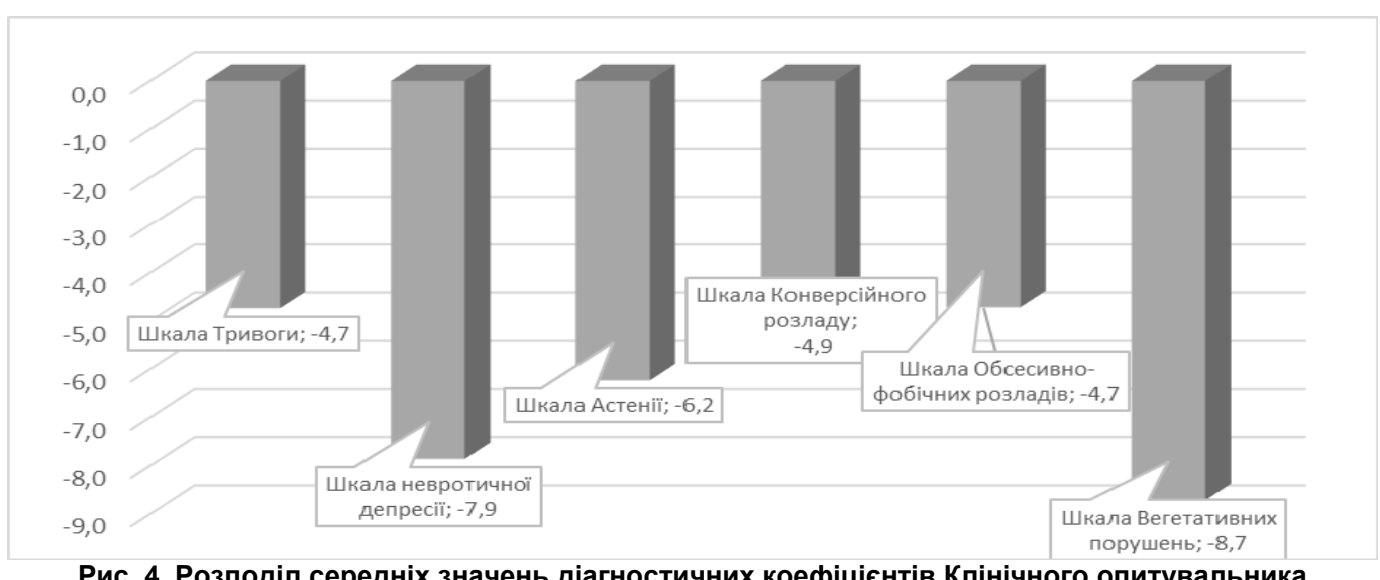

Рис. 4. Розподіл середніх значень діагностичних коефіцієнтів Клінічного опитувальника виявлення та оцінки невротичних станів

Для зіставлення показників усіх шкал методик і виявлення взаємозв'язків між ними ми застосували процедуру кореляційного аналізу за методом К. Пірсона. Розрахунки проводилися за допомогою комп'ютерної програми статистичної обробки даних психологічних досліджень SPSS.19
[4]. Для пошуку взаємозв'язків між досліджуваними змінними було обрано показник кількості ознак межового розладу особистості (МРО), з одного боку, і показники всіх використаних у дослідженні методик, з іншого. Результати кореляційного аналізу подано у табл. 2.

Результати кореляційного аналізу (зіставлення діагностичного показника кількості ознак межового розладу особистості з показниками інших методик дослідження)

\begin{tabular}{|c|c|c|c|}
\hline № & & Показники методик & $\begin{array}{c}\text { Значення коефіцієнта } \\
\text { кореляції Пірсона (r) }\end{array}$ \\
\hline \multicolumn{4}{|c|}{ Методика Велика П'ятірка "5PFQ" } \\
\hline 1 & \multirow[t]{5}{*}{ Показник кількості ознак МРО } & Екстраверсія - інтроверсія & $-0,116$ \\
\hline 2 & & Прихільність - відособленість & $-0,363^{*}$ \\
\hline 3 & & Самоконтроль - імпульсивність & $-0,114$ \\
\hline 4 & & Емоціона стійкість - емоційна нестійкість & $-0,423^{*}$ \\
\hline 5 & & Практичність - експресивність & $-0,194$ \\
\hline \multicolumn{4}{|c|}{ Клінічний опитувальник (К. К. Яхін, Д. М. Менделєвич) } \\
\hline 1 & \multirow[t]{6}{*}{ Показник кількості ознак МРО } & Шкала тривоги & 0,317 \\
\hline 2 & & Шкала невротичної_депресії & $0,505^{\star *}$ \\
\hline 3 & & Шкала астенії & $0,535^{* *}$ \\
\hline 4 & & Шкала конверсійного розладу & $0,441^{*}$ \\
\hline 5. & & Шкала обсесивно-фобічного розладу & $0,412^{*}$ \\
\hline 6 & & Шкала вегетативних порушень & 0,146 \\
\hline
\end{tabular}

** Кореляція значуща на рівні $p<0,01$.

Таким чином, кореляційний аналіз виявив тенденції значущого взаємозв'язку між показником кількості ознак межового розладу особистості (МРО) і наступними шка- лами, а саме: прихильність - відособленість $(r=-0,363$, $p<0,05)$ і емоційна стійкість $(r=-0,423, p<0,05)$. Звертають на себе увагу позитивні кореляційні взаємозв'яз- 
ки показника кількості ознак MPO зі шкалами клінічного опитувальника. Найбільш виділяються тут шкала астенії $(r=0,535, p<0,01)$ і шкала невротичної депресії $(r=0,505, p<0,01)$. Значущі взаємозв'язки виявлені зі шкалами конверсійного розладу $(r=0,441, p<0,05)$ i обсесивно-фобічних розладів $(r=0,412, p<0,05)$.

Висновки. Узагальнюючи результати статистичного аналізу психологічних особливостей осіб із ознаками межового розладу особистості можна стверджувати таке:

1. Межовий розлад особистості (МРO) - це розлад психіки, за якого спостерігається підвищена емоційна нестабільність поведінки. Особи з МРО схильні до імпульсивних учинків, різких перепадів настрою, агресивної поведінки і депресивності.

2. Для осіб із межовим розладом особистості характерна емоційна біль, уразливість, скачки від ідеалізації до повного знецінення одних і тих самих людей, або ситуацій, нездатність, навіть доклавши зусиль, ефективно впливати на свої переживання, емоції, реакції в ситуаціях стресу в когнітивній, поведінковій та емоційній сорерах.

3. Кореляційний аналіз виявив тенденції значущого взаємозв'язку між показником кількості ознак межового розладу особистості (MPO) і такими показниками, як емоційна лабільність (нестійкість емоцій), імпульсивність та самоушкоджувальна поведінка. Саме ці показники є важливими діагностичними критеріями межового розладу особистості.

4. Високий рівень вияву ознак межового розладу особистості супроводжується такими психічними станами дезадаптації, як невротична депресія, астенія, напруженість і тривожність.

Таким чином, особам із виразністю ознак межового розладу особистості характерні емоційний дискомфорт, імпульсивність, відособленість і емоційна нестійкість. Ці характеристики особистості спостерігаються на тлі вираженості станів психічної дезадаптації, астенії та переживань невротичної депресії. Супутніми із виявами ознак межового розладу особистості, імовірно, $є$ конверсійне і обсесивно-фобічні розлади особистості.
Список використаних джерел

1. Бейтман Э.У. Лечение пограничного расстройства личности с опорой на ментализацию/ Э. У. Бейтман, П. Фонаги. - М. : Институт общегуманитарных исследований, 2014. - 248 с

2. Ласовская Т. Ю. Опросник для диагностики пограничного личностного расстройства формы "А" // Консультативная психология и психотерапия. - 2014. - Т. 22. - № 2. - С. 48-77.

3. Лайнен М. Когнитивно-поведенческая терапия пограничного расстройства личности / М. Лайнен. - М. : Вильямс, 2015. - 592 с.

4. Наследов А. Д. SPSS 19. Профессиональный статистический анализ данных / А. Д. Наследов. - СПб. : Питер, 2011. - 400 с.

5. Отчет Министерства социальной политики Украины о состоянии психического здоровья украинцев [Электронный ресурс]. - Режим доступу: https://ru.tsn.ua/ukrayina/ukraina-zanimaet-pervoe-mesto-po-kolichestvupsihicheskih-rasstroystv-v-evrope-1009380.html.

6. Хромов А. Б. Пятифакторный опросник личности: учебно-метод пособ. / А. Б. Хромов. - Курган : Изд-во Курганск. ун-та, 2000. - 23 с.

7. Яхин К. К. Клинический опросник для выявления и оценки невротических состояний / К. К. Яхин, Д. М. Менделевич. - М., 1998. - С. 545-552.

8. Evaluation of naltrexone for dissociative symptoms in borderline personality disorder / C. Schmahl, N. Kleindienst, M. Limberger and other // International Clinical Psychopharmacology. - 2012. - Vol. 27. - № 1. P. 61-68.

\section{Reference}

1. Beitman E. U. Lechenie pogranichnogo rasstroistva lichnosti s oporoi na mentalizatsiiu / E. U. Beitman, P. Fonagi. - M. : Institut obshchegumanitarnykh issledovanii, 2014. $-248 \mathrm{~s}$.

2. Lasovskaia T. lu. Oprosnik dlia diagnostiki pogranichnogo lichnostnogo rasstroistva formy "A" // Konsultativnaia psikhologiia i psikhoterapiia. 2014. - Tom 22. - № 2. - S. 48-77.

3. Lainen M. Kognitivno-povedencheskaia terapiia pogranichnogo rasstroistva lichnosti / Marsha M. Lainen. - M. : Viliams, 2015 - 592 s.

4. Nasledov A. D. SPSS 19. Professionalnyi statisticheskii analiz dannykh [Tekst] / A. D. Nasledov. - SPb. : Piter, 2011. - $400 \mathrm{~s}$

5. Otchet Ministerstva sotsialnoi politiki Ukrainy o sostoianii psikhicheskogo zdorovia ukraintsev [Elektronnyi resurs]: https://ru.tsn.ua/ ukrayina/ukraina-zanimaet-pervoe-mesto-po-kolichestvu-psihicheskih-

rasstroystv-v-evrope-1009380.html

6. Khromov A. B. Piatifaktornyi oprosnik lichnosti: Uchebnometodicheskoe posobie / A. B. Khromov. - Kurgan: Izd-vo Kurganskogo universiteta, 2000. - $23 \mathrm{~s}$

7. lakhin K. K. Klinicheskii oprosnik dlia vyiavleniia i otsenki nevroticheskikh sostoianii / K. K. lakhin, D. M. Mendelevich. - M., 1998. - S. 545-552.

8. Evaluation of naltrexone for dissociative symptoms in borderline personality disorder [Текст] / Schmahl C., Kleindienst N., Limberger M., Ludäscher P., Mauchnik J., Deibler P., Bohus M., Brünen S., Hiemke C., Lieb K., Herpertz S., Reicherzer M. // International Clinical Psychopharmacology. - 2012. - Vol. 27. - № 1. - P. 61-68. надійшла до редколегії 01.11.18

\section{В. Морозова, студ.}

Николаевский национальный университет имени В. О. Сухомлинского, Херсон

\section{ПСИХОЛОГИЧЕСКИЕ ОСОБЕННОСТИ ЛИЦ С ПОГРАНИЧНЫМ РАССТРОЙСТВОМ ЛИЧНОСТИ}

Представлены результаты эмпирического исследования психологических особенностей лиц с признаками пограничного расстройства личности. Показано, что эмоциональная лабильность (неустойчивость эмоций), импульсивность и самоповреждающее поведение являются важными диагностическими критериями пограничного расстройства личности. Высокий уровень проявления признаков пограничного расстройства личности сопровождается такими психическими состояниями дезадаптации, как невротическая депрессия, астения, напряженность и тревожность.

Ключевые слова: пограничное расстройство личности, невротические состояния, неустойчивость эмоций, самоповреждающее поведение, импульсивность, тревожность.

V. Morozova, stud.

V. Sukhomlinsky National University of Mykolaiv, Kherson

\section{PSYCHOLOGICAL FEATURES OF PEOPLE WITH BORDERLINE PERSONALITY DISORDERS}

The article presents the results of an empirical study of the psychological features of people with signs of borderline personality disorder. The study involved 40 people with signs of borderline personality disorder aged 14-56 years. According to the purpose of the study, the following tasks have been set: To investigate personality with borderline disorder; Identify and evaluate the neurotic states of a person with a borderline personality disorder; Conduct correlation analysis to investigate trends in the relationship between the indicator of the number of signs of borderline disorder and personal characteristics. The following research methods were used: $5 P F Q$ Big Five technique (R. McCray, P. Costa), Clinical questionnaire for the detection and evaluation of neurotic conditions (KK Yakhin, DM Mendelevich) and Methods for diagnosing borderline personality disorder (TY Lasovskaya, CP Korolenko, SV Yaechnikov). The data obtained were subjected to a mathematical and statistical analysis procedure using the SPSS Statistic program. It is proved that emotional lability (instability of emotions), impulsiveness and self-harming behavior are important diagnostic criteria of a borderline personality disorder. High level of manifestation of signs of borderline personality disorder is accompanied by such mental states of disadaptation as neurotic depression, asthenia, tension and anxiety.

Keywords: borderline personality disorder, neuroticism, instability of emotions, self-damaging behavior, impulsiveness, anxiety. 